\title{
The effect of aerobic exercise along with resveratrol supplementation on myocardial AMPK and MAFbx gene expression of diabetic rats
}

\author{
Bentollhoda Esmailee $^{1}$ (D) Ahmad Abdi $^{2}$, Asieh Abbassi Daloii ${ }^{3}$ (D) Parvin Farzanegi $^{4}$ (D) \\ ${ }^{1}$ Ph.D. Candidate in Department of Sport Physiology, Ayatollah Amoli Branch, Islamic Azad University, Amol, I. R. Iran. \\ 2 Corresponding author; Department of Sport Physiology, Ayatollah Amoli Branch, Islamic Azad University, Amol, Iran. \\ Tel: +981143217126Ｆax:+981143217009_Email:a.abdi58@gmail.com \\ ${ }^{3}$ Department of Sport Physiology, Ayatollah Amoli Branch, Islamic Azad University, Amol, Iran. \\ ${ }^{4}$ Department of Exercise Physiology, Sari Branch, Islamic Azad University, Sari, Iran.
}

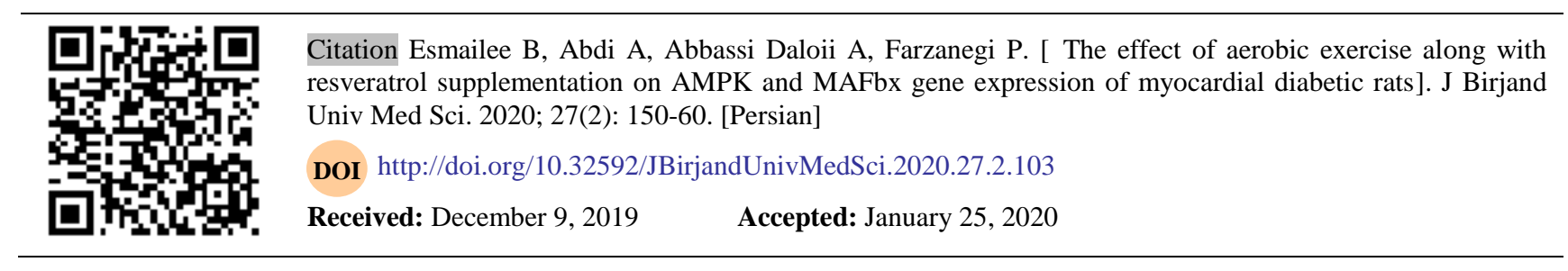

\begin{abstract}
Background and Aim: Diabetes is a metabolic disease that is associated with heart injury. It has been shown that exercise training and resveratrol can improve the cardiac structure and function of diabetic subjects. The aim of the present study was to examine the effect of aerobic training along with resveratrol on gene expression of AMPK and MAFbx on myocardial AMPK and MAFbx gene expression of diabetic rats.

Materials and Methods: In this experimental study, 40 males Wistar rats were randomly were divided into 5 groups: control (CN), diabetes (DM), diabetes-Resveratrol (RDM), diabetes-aerobic exercise (TDM), diabetes-aerobic exercise-Resveratrol (RTDM).Training groups have performed a running program on the treadmill for 8 weeks. Resveratrol $(20 \mathrm{mg} / \mathrm{kg}) \mathrm{was}$ injected subcutaneously 8 weeks for RDM and TRDM groups. 48 hours after the last training session, rats were anesthetized. Changes in the expression of AMPK and MAFbx myocardial genes were quantified using real-time PCR methods.

Results: The results of the present study showed a reduction in AMPK expression $(\mathrm{P}<0.001)$ and an increase in MAFbx $(\mathrm{P}<0.001)$ in cardiomyocytes in DM groups compared to $\mathrm{CN}$ group.

AMPK expression was significantly increased in TRDM group compared to DM ( $p=0.009), R D M(p=0.011)$ and TDM ( $p=0.043$ ) groups. MAFbx expression of cardiomyocytes in RDM ( $\mathrm{p}=0.012)$, TDM $(\mathrm{p}<0.001)$ and TRDM ( $<0.001)$ groups had significantly reduction compared to DM group. Also, MAFbx expression was significantly reduction in TRDM groups compared to RDM $(\mathrm{p}=0.041)$ groups.

Conclusion: Long-term aerobic exercise, with and without resveratrol consumption it may cause to reduce the genomic indicators of atrophy and increase myocardial hypertrophy in diabetic rats.
\end{abstract}

Key Words: AMPK; Diabetic Rats; Exercise; MAFbx; Resveratrol 


\section{اثر تمرين هوازى همراه با مكمل رزوراترول بر بيان}

\section{رنهاى AMPK و MAFbx ميو كارد موشىهاى صحر ائى ديابتى}

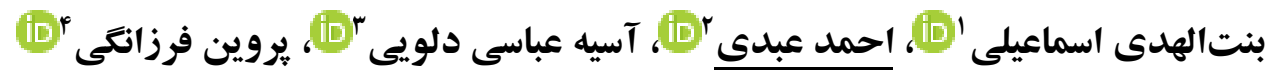

\section{جكيده}

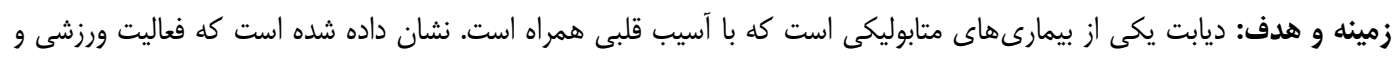

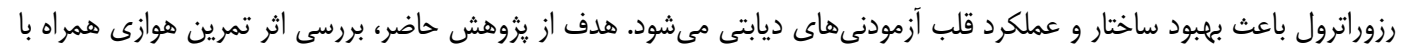

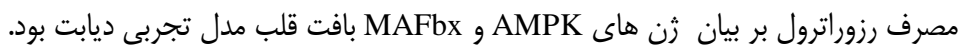

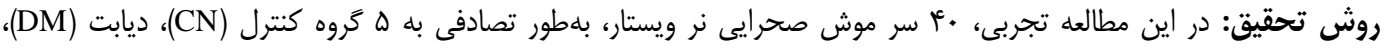

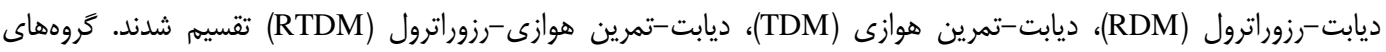

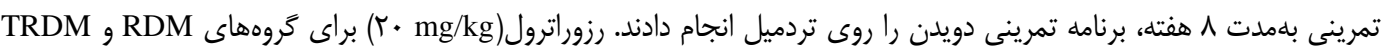

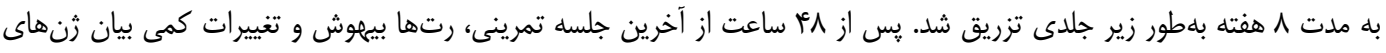

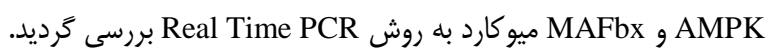

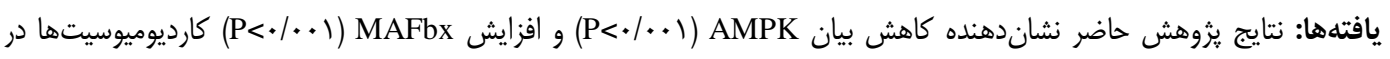

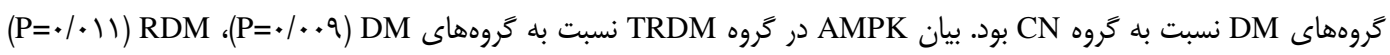

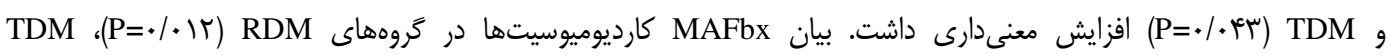

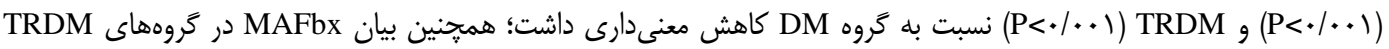

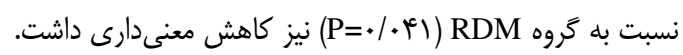

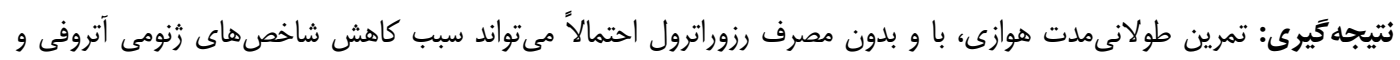
افزايش هييرتروفى ميوكارد موشهاى صحر ائى ديابتى شود.

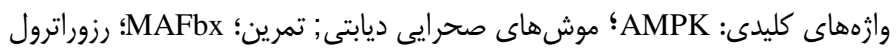

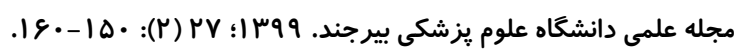
يذيرش: ه//|| ||

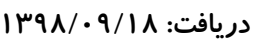

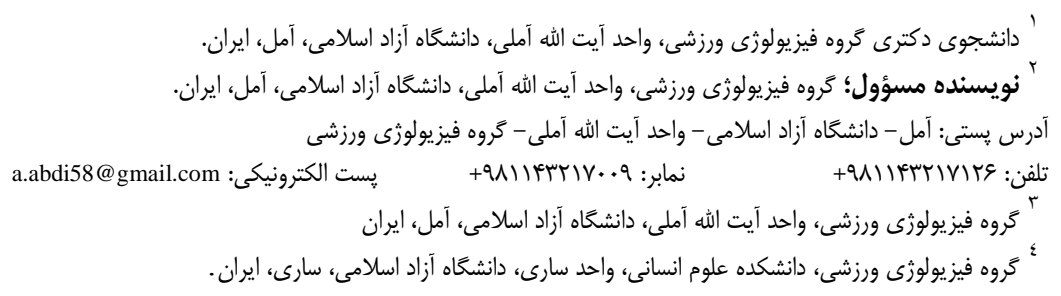


يروتئين MuRF1 كه در آتروفى عضلانى اسكلتى نقش

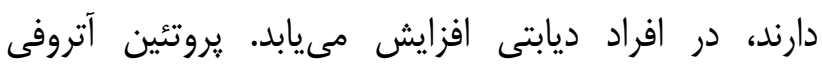

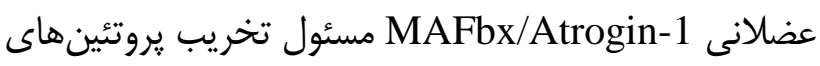
تعديلكننده يوبيكويتين مىباشد (V) MAFbx/Atrogin-1 فيزيولوزيك در شرايط in vivo مي شود (N). مطالعات نشان

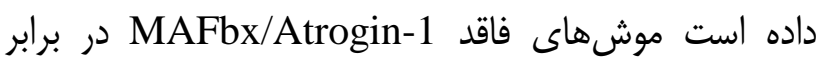

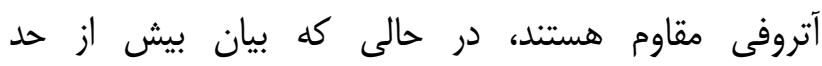
MAFbx/Atrogin-1

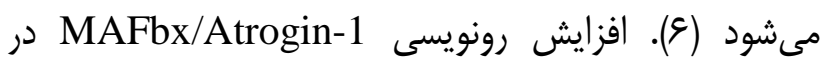

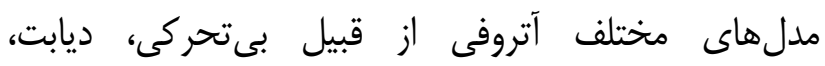

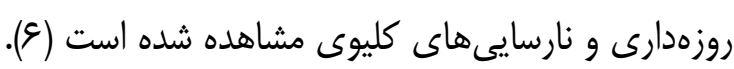
در حال حاضر روشهاى درمان آتروفى عضلانى ناشى از ازئ دارئ

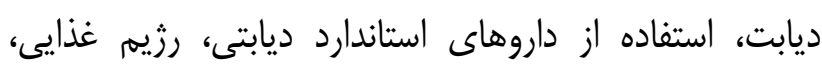

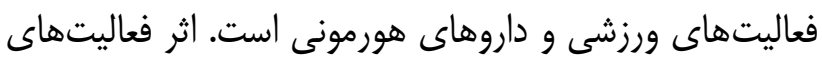

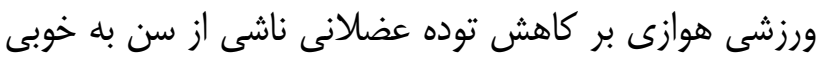

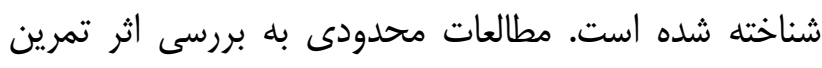

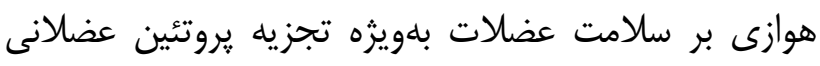

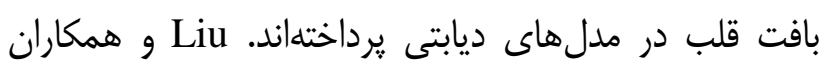

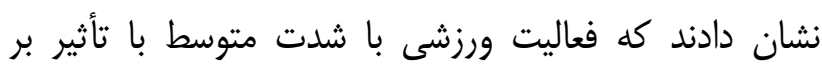

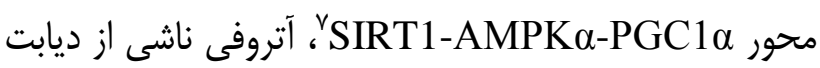
ديابت را در موشهاى db/db كاهش مىدهد (q).

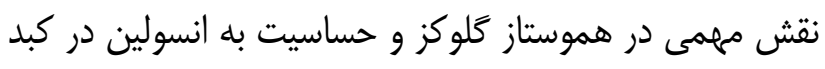

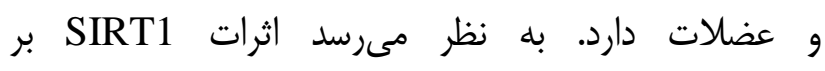

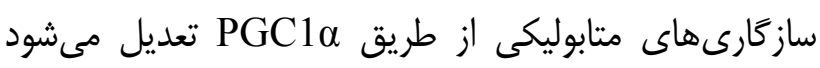

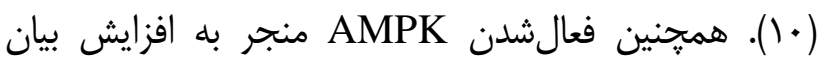

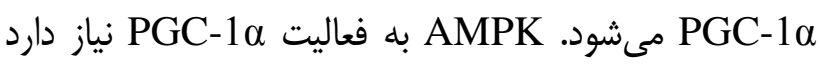

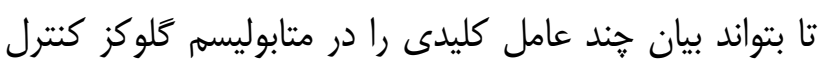

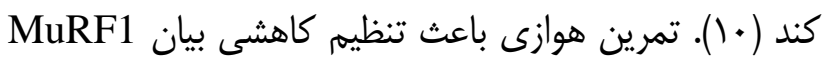

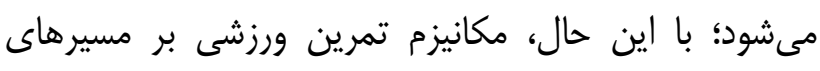

\footnotetext{
${ }^{6}$ Muscle RING-finger protein 1

${ }^{7}$ Peroxisome proliferator-activated receptor gamma coactivator 1alpha
}

مقل مله

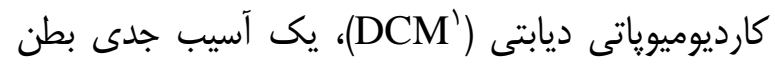
قلبى ناشى از ديابت بارئي

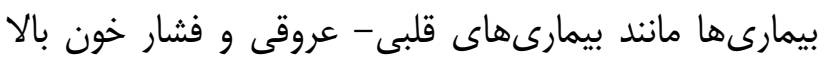

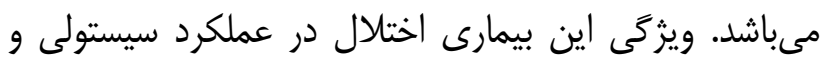

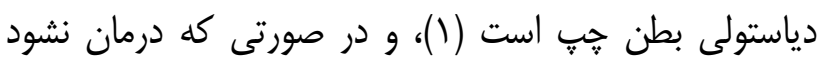

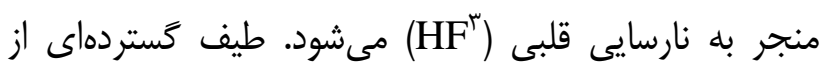

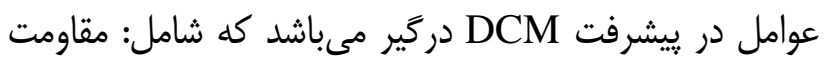

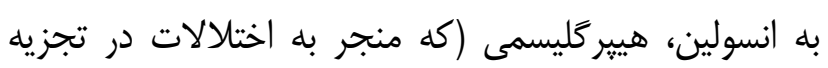

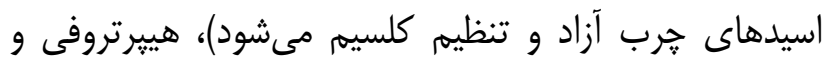

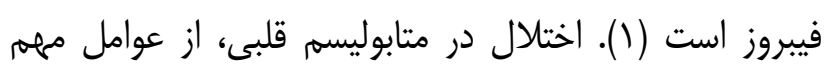

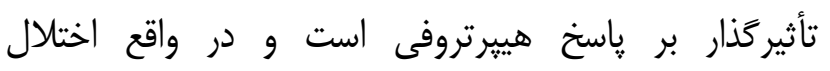

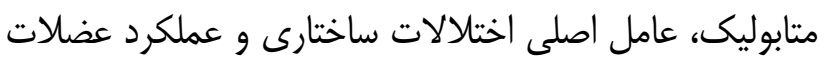

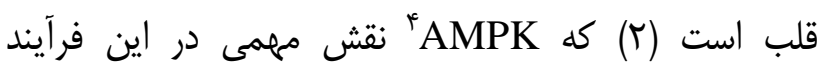

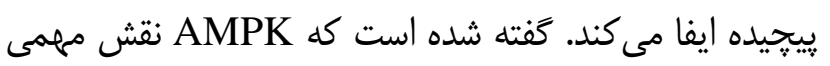

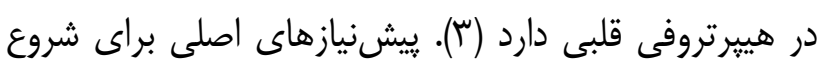
و كسترش هييرتروفى قلبى؛ رشد سلول، سنتز يروتئئين،

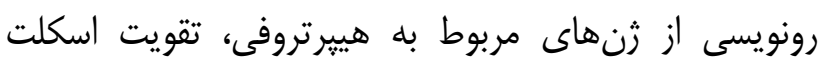

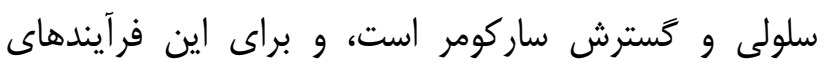

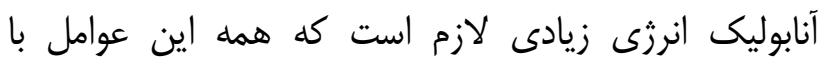

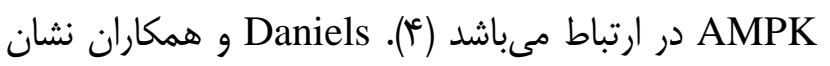

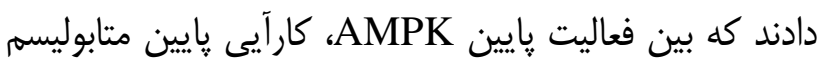

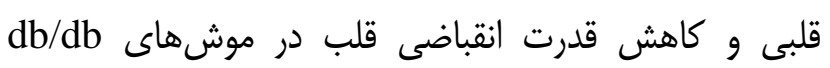

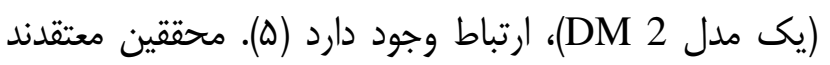
كه ديابت بر فعالشدن AMPK تأثير كذاشته، كه به به نوبه

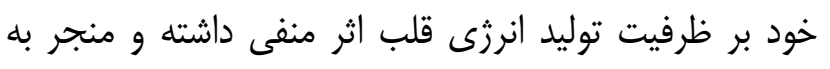

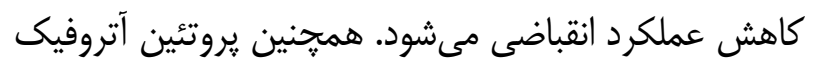
Atrogin-1 نيز شناخته مىشود و

\footnotetext{
${ }^{1}$ Diabetic cardiomyopathy

2 Diabetes mellitus

${ }^{3}$ Heart failure

${ }^{4}$ AMP-activated protein kinase

5 muscle atrophy F-box
} 
سارى (كد تأييد شد. پس از انتقال موشهاى صحرايى به آزمايشگاه،

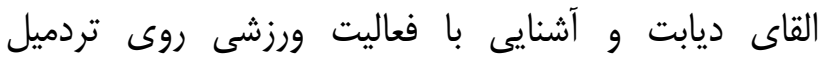

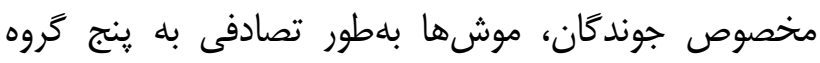

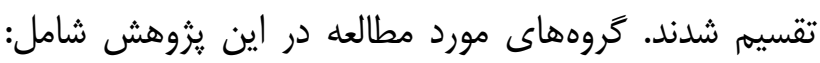

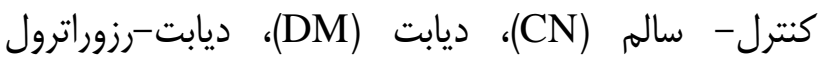

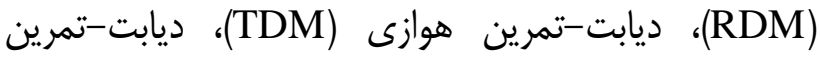
هوازى -رزوراترول (RTDM) بودند. موشهاى (RT) يك برنامه هشتهفتهاى (ه روز هفته) تمرين هوازى را اجرا

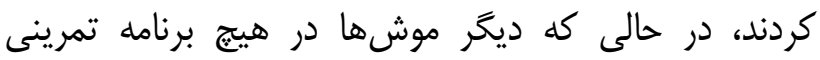
شركت داده نشدند.

\section{روش القاى ديابت:}

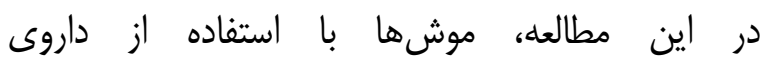
استريتوزتوسين (شركت سيخماى آلمان) ديابتى شدند. القاى

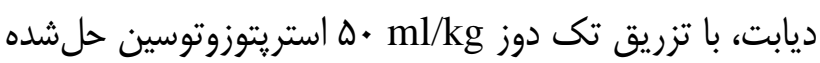

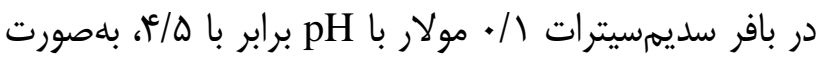
داخل صفاقى صورت گرفت. براى تشخيص ديابتىبودن

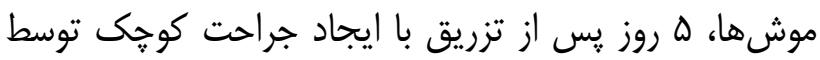

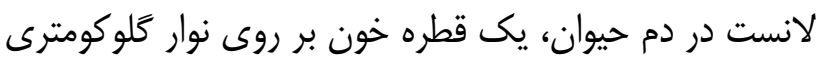

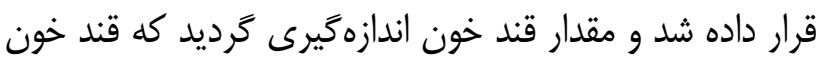

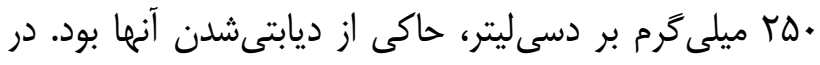

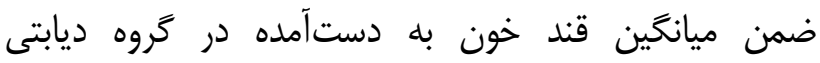

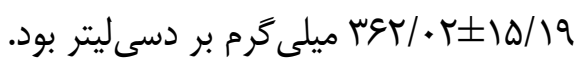

\section{يروتكل تمرين:}

در جدول شماره 1 يروتكل تمرين هوازى برو براى موشهاى صحرايى ديابتى نشان داده شده است. قبل از

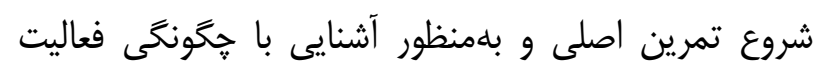

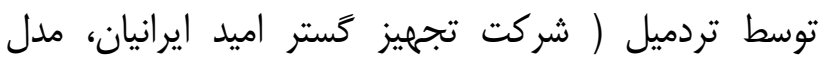

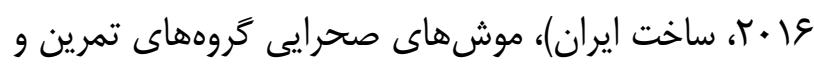

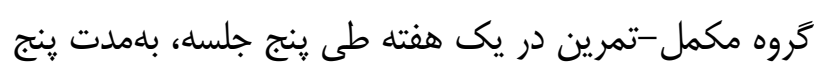

\footnotetext{
${ }^{3}$ Strptozotosin
}

سيخنالينگ آتروفى در ديابت همرٌنان ناشناخته است. علاوه

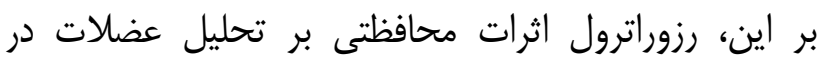

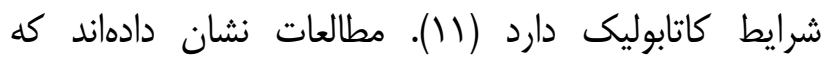

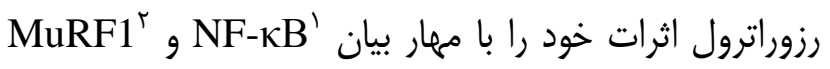

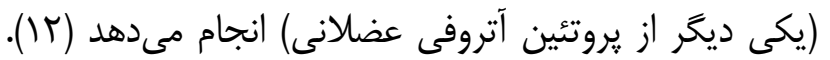

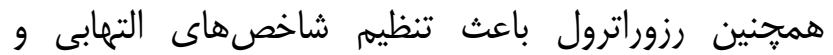
آتروفى مىشود (1). در موشهاى ديابتى، رزوراترول باعث

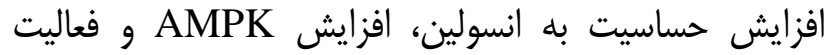
شده و سيتوكينهاى التهابى را كاهش مى مدهد (IRT1 در اين يثوهش سعى شد تا به طور همزمان، اثر تمرين

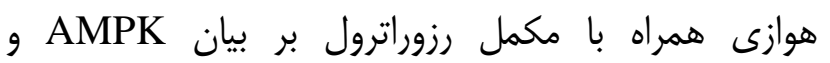

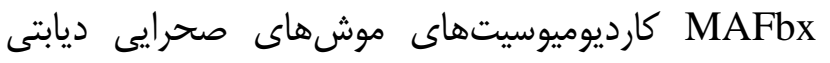
بررسى گردد.

\section{روش تحقيق}

\section{نمونهها:}

در اين يزوهش تجربى، تعداد • ع سر موش صحرايى نر

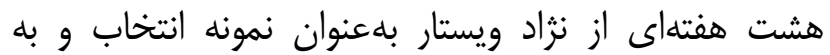

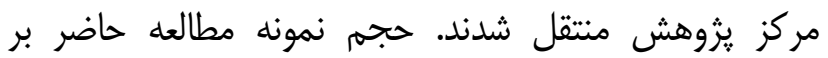

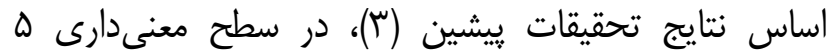

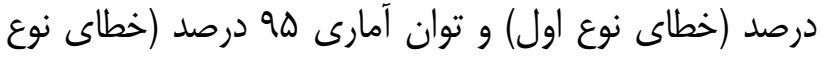
دوم) و با استفاده از نرمافزار 18.2 .1 Medcalc در هر گروه) تعيين شد. معيار خروج از مطالعه، عدم اجراى إد ندار

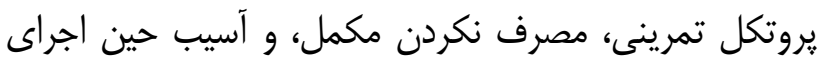
تمرين بود. حيوانات در دماى r ب بr درجه سانتى

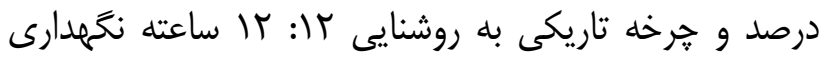

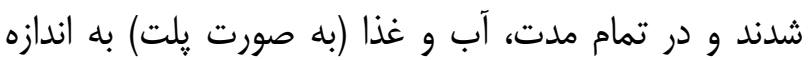
كافى و آزادانه دريافت كردند. موازين اخلاقى مات كار با حئ حيوانات

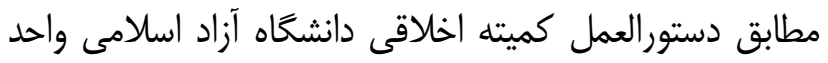

\footnotetext{
${ }^{1}$ Nuclear factor kappa-light-chain-enhancer of activated B cells

${ }^{2}$ Muscle RING-finger protein-1
} 


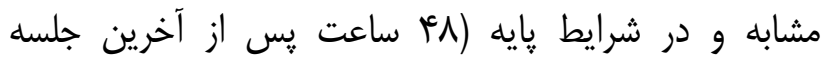

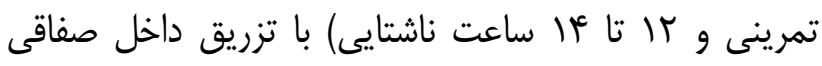

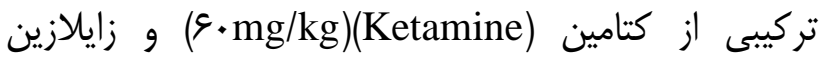
(ه mg/kg)(Xylazine)

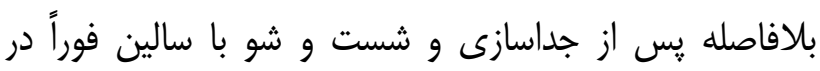

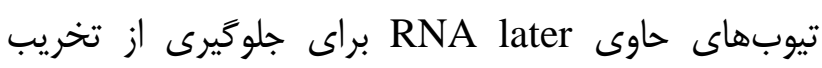

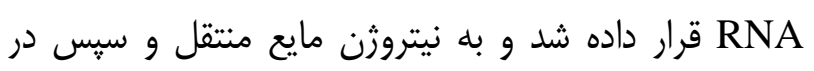

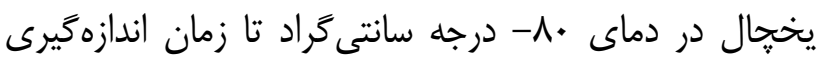

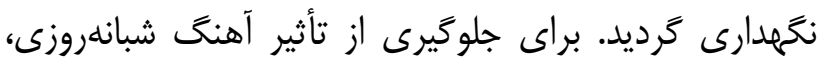

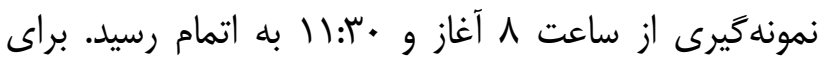

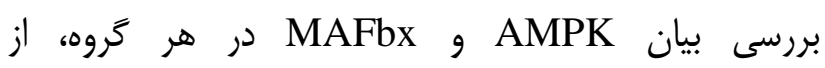
تكنيك Real Time PCR استفاده شد. ابتدا طراحى يرايمر

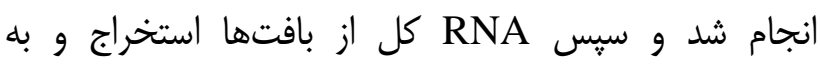

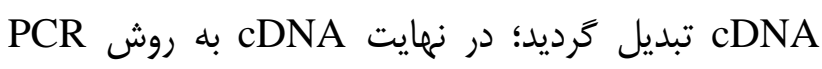
تكثير شد و از نظر بيان زن هاى ذكرشده مورد بردئ برسى قرار كرفت.

\section{روش اندازهتيرى بيان AMPK و MAFbx:}

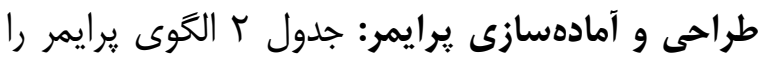

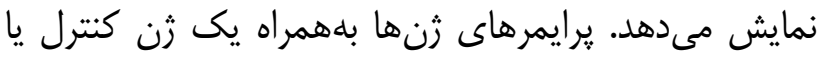
رفرانس Glyceraldehyde 3-phosphate ) GAPDH (dehydrogenase طراحى شد و براى سنتز به شركت سيناكلون (Sinaclon) سفارش داده شد.
دقيقه با سرعت • (1-1 متر بر دقيقه با شيب صفر فعاليت

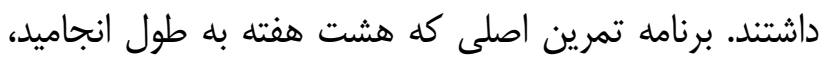
بدين صورت انجام شد كه در هفته آغازين با سرعت ها هام متر

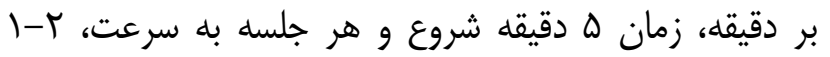

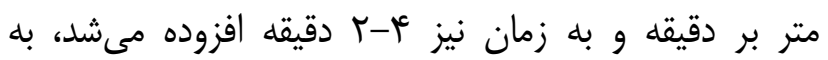

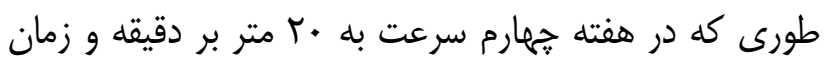

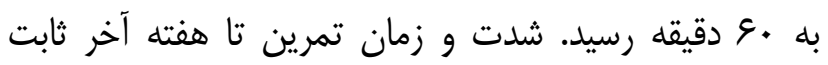

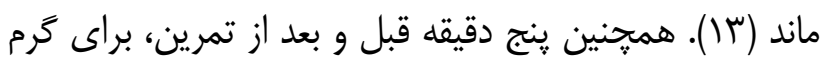
و سرد كردن حيوانات در نظر كرفته شد.

\section{نحوه مصرف رزوراترول:}

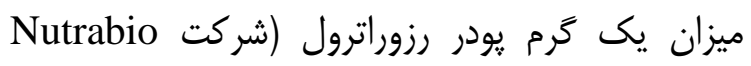
آمريكا، با درجه فارماكولوزى و خلوص 99/AV درصد

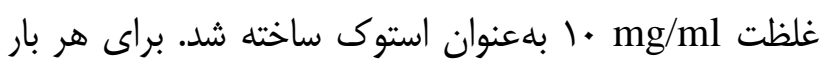

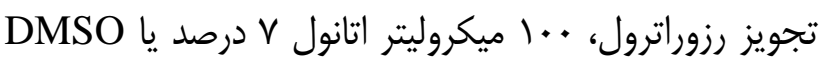

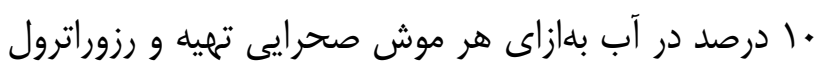

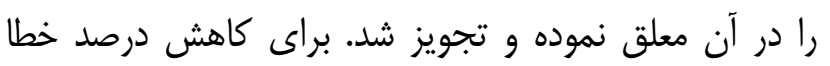

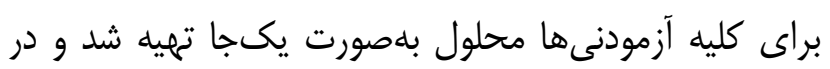

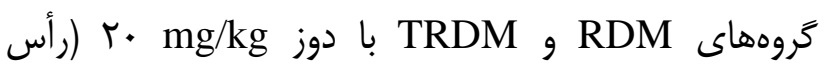
ساعت 9 صبح) بلهصورت درون صفاقى بلهمدت ها ه روز در هفته بلمطول 1 هفته تزريق شد (بأهوت درن). روش نمونهَيرى از بافت قلب:

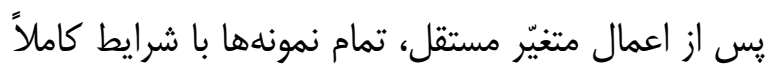
جدول ا- بروتكل تمرينى هوازى براى موشهائ صحرايى

\begin{tabular}{|c|c|c|c|c|c|c|c|c|}
\hline هشتم & هفتم & ششم & ينجم & جهارم & سوم & دوم & اول & هفته \\
\hline 4. & 4. & 8 . & 4. & q. & f. & r. & $\Delta$ & مدت (دقيقه) \\
\hline r. & $r$. & $r$. & r. & $r$. & 19 & IV & 10 & سرعت(متر بر دقيقه) \\
\hline
\end{tabular}

جدول r- الكَوى برايمر AMPK و MAFbx و زن كنترل داخلى

\begin{tabular}{cc}
\hline Genes & Sequence $\left(\mathbf{5}^{\prime} \rightarrow \mathbf{3}^{\prime}\right)$ \\
\hline F AMPK & TGT GTT CAA AGT CTG CTG CC \\
\hline R AMPK & ACG CTG TAA GGT CTG GTC AA \\
\hline F MAFbx & AGGGCAGGTGGATTGGAGAAGA \\
\hline R MAFbx & GTTGGGGTGAAAGTGAGACGGAG \\
\hline F GAPDH & AAGTTCAACGGCACAGTCAAGG \\
\hline R GAPDH & CATACTCAGCACCAGCATCACC \\
\hline
\end{tabular}


محاسبه تغييرات بيان زنها با هct، براى كمىكردن نتيجه

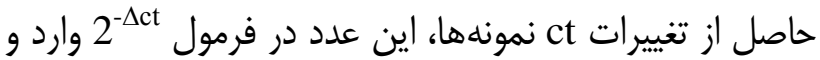

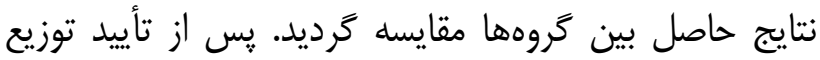

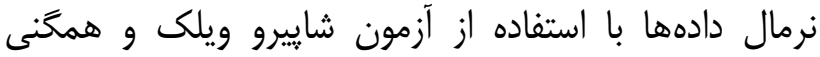

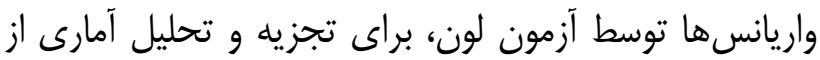
آزمون آناليز واريانس يكىطرفه توسط آزمن آزمون تعقيبى توكى استفاده تجاه شد. تمام دادهها بلهصورت ميانكين \pm انحراف معيار ارائه

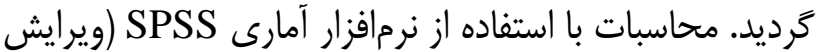

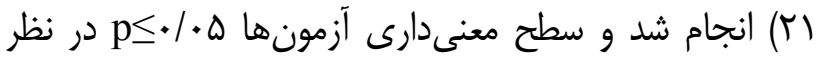
كرفته شد.

يافته ها تجزيه و تحليل دادهها نشان داد كه تفاوت معنىدارى در

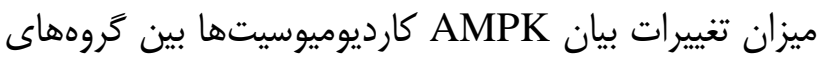

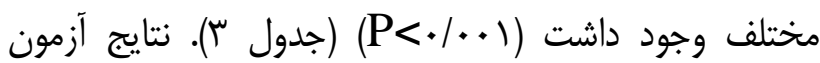
تعقيبى نشان داد بين گروههاى كنترل-سالم با ديابت

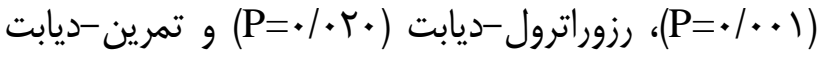

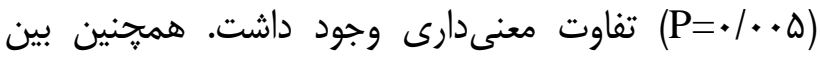

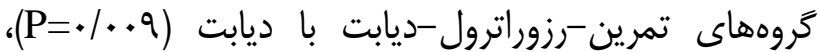

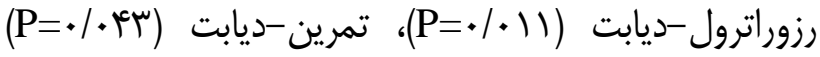
اختلاف معنى دارى مشاهده شد (نمودار ()).

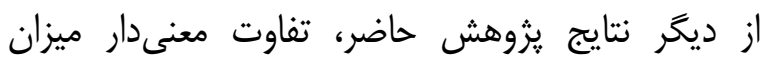

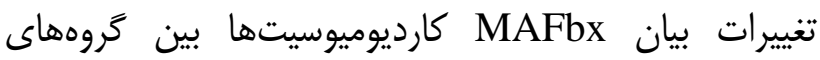

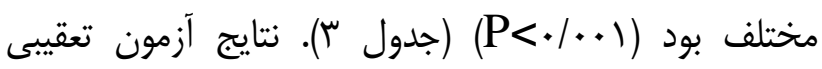

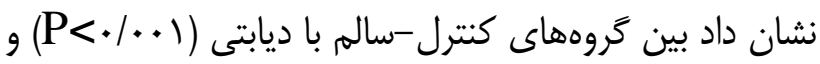

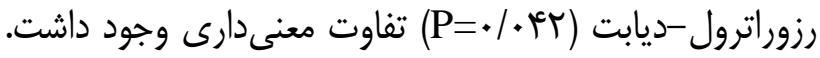

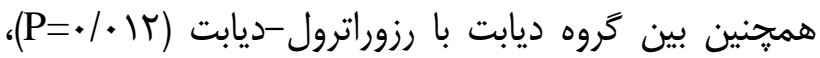

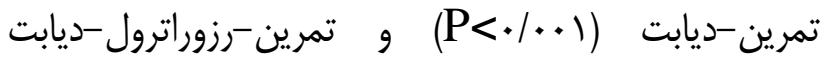

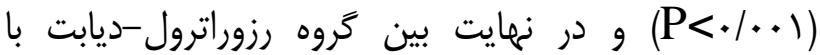

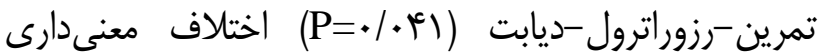

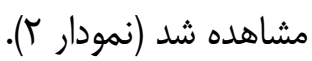

استخراج RNA :RNA با استفاده از كيت Kiagen (آلمان) و مطابق با دستورالعمل شركت سازنده استخراج شد. انجام Real time-PCR: يس از استخراج RNA با خلوص و غلظت بالا از تمامى نمونههاى مورد مطالعه، مراحل

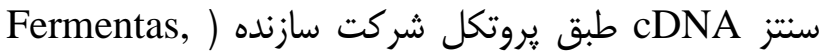

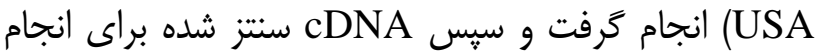
واكنش رونويسى معكوس مورد استفاده قرار گرفت. ابتدا كليه يرايمرهاى طراحىشده مربوط به تمامى زنها، مورد بررسى موسى مورد

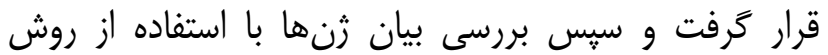
كمى RT-qPCR انجام گرفت. براى انجام RT-qPCR، ابتدا با استفاده از محلول كيازول، RNA كل سلولها استخراج شد؛ سيس كيفيت

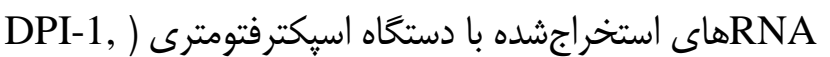
(Kiagen

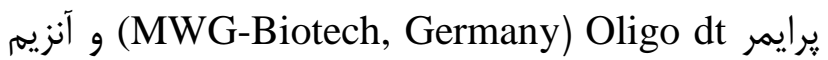
نسخلبردارى معكوس (Fermentas) بر اساس يروتكل مربوطه تهيه شد. هر واكنش PCR با استفاده از PCR SYBER و (Applied Biosystems) master mix Applied ) ABI Step One در دستخاه Green Biosystems, Sequences Detection Systems. Focter City, CA گرفت. تعداد • r سيكل براى هر קرخه Real-Time PCR

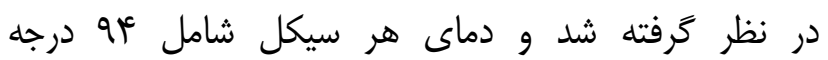

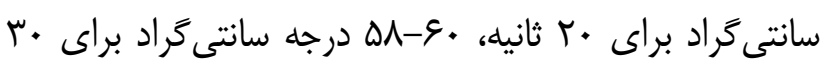

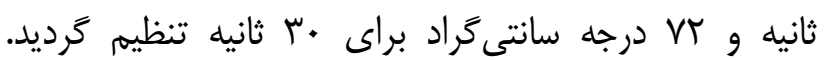
نسبت بيان زنهاى مورد بررسى در اين مطالعه، با روش لئه مقايسهاى هرخه آستانه (Thereshold Cycle: CT) مورد ارزيابى قرار خرفت.

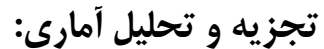

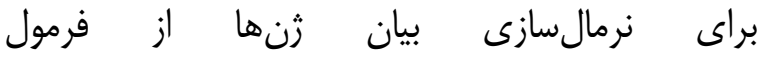

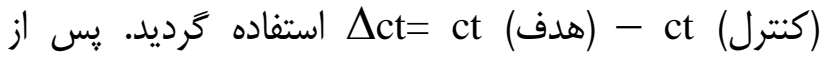


جدول س- مقايسه متغيرها در يسآزمون بين كَروهها

\begin{tabular}{|c|c|c|c|c|}
\hline Sig & نسبت F & df & \multicolumn{2}{|c|}{ متغيّر } \\
\hline \multirow{2}{*}{$\cdot 1 \ldots *$} & \multirow{2}{*}{$1 \cdot /$ IV } & f & بين گروهها & \multirow{2}{*}{ AMPK } \\
\hline & & $r$. & درون گروه & \\
\hline \multirow{2}{*}{$.1 \ldots *$} & \multirow{2}{*}{ IE/KTD } & i & بين گروهها & \multirow{2}{*}{ MAFbx } \\
\hline & & $r$. & درون گروه & \\
\hline
\end{tabular}

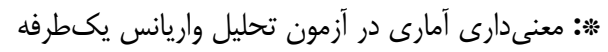

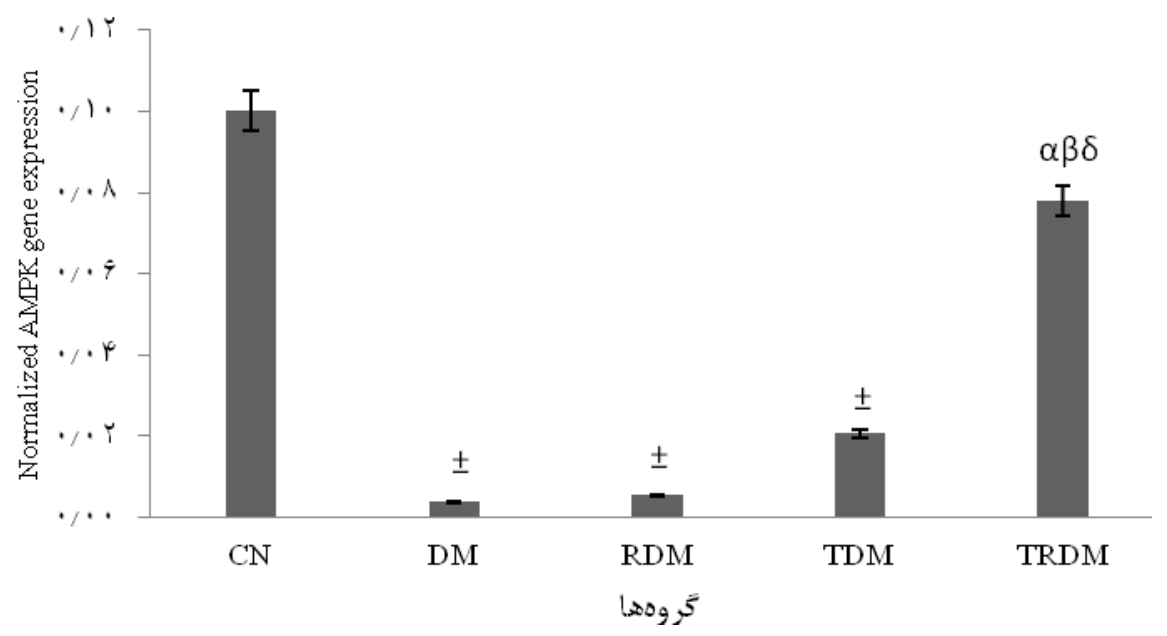

نمودار ا - تغييرات بيان AMPK كارديوميوسيتها در تحروهاى مختلف. 土: تفاوت با كنترل-سالم (CN)، d: تفاوت با ديابت

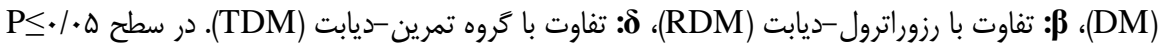

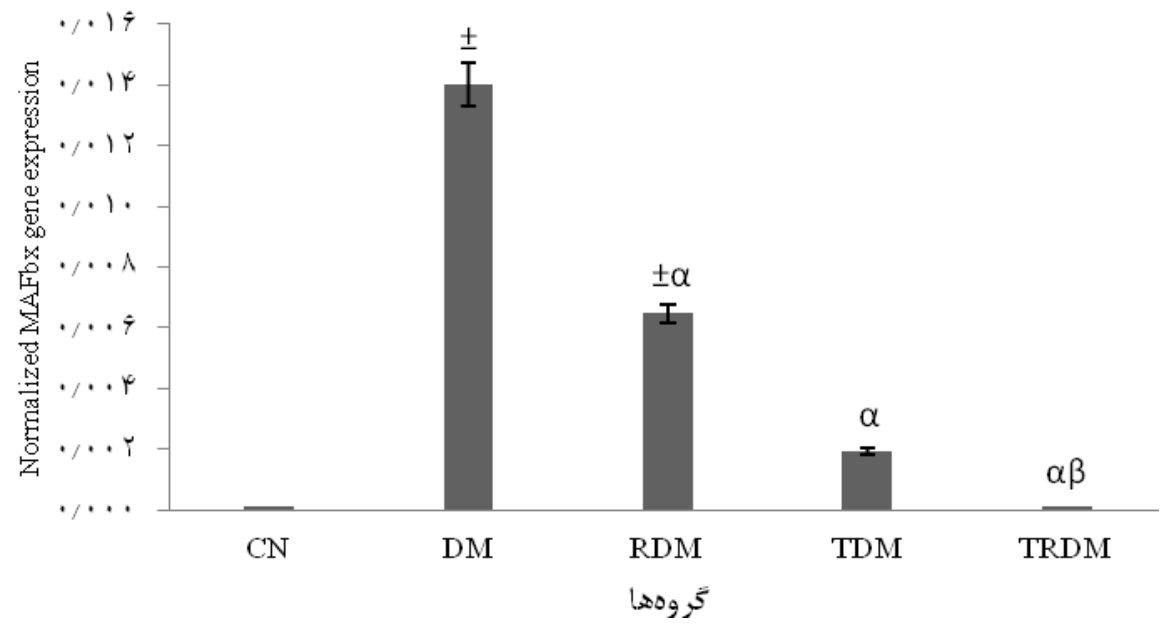

نمودار ץ- تغييرات بيان MAFbx كارديوميوسيتها در ترووه هاى مختلف: 士: تفاوت با كنترل-سالم (CN)، ג: تفاوت با

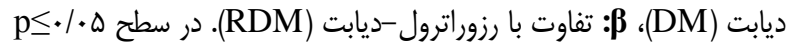


ياسخ سازگًارانه براى افزايش نياز به انرزى، باعث فعالشدن

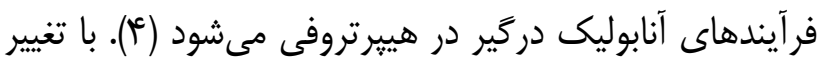
در سطح انرزى درونسلولى، AMPK به افزايش نسبت

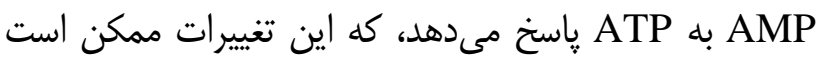

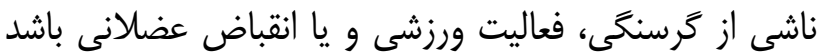

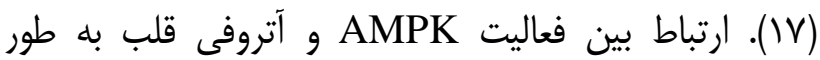

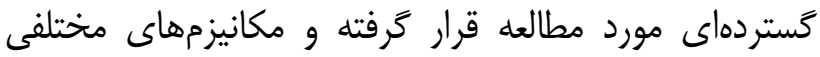
ييشنهاد شده است. در سطح سلولى، هييرتروفى قلب با تعادل مثبت يروتئين افزايش مىيابد. بلنظر مىرسد تغيير در اين سئل

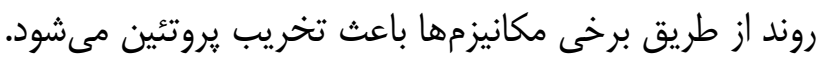
مهمترين مسير تخريب يروتئين، سيستم يوبيكويتين يروتئازوم (UPS)

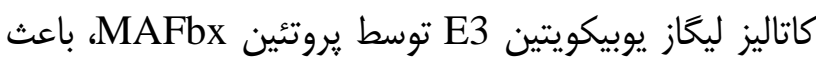

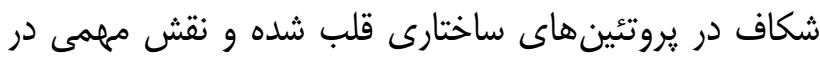

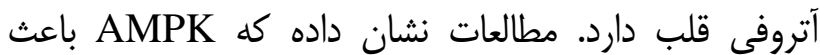
تنظيم رونويسى MAFbx شده و باعث كاهش تخريب

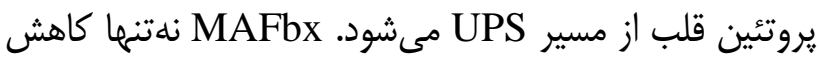

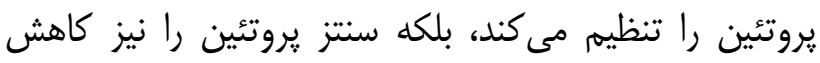

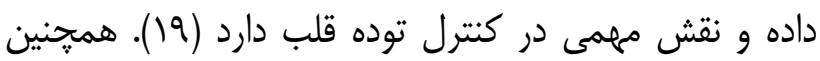

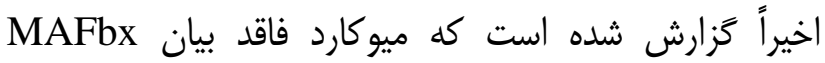

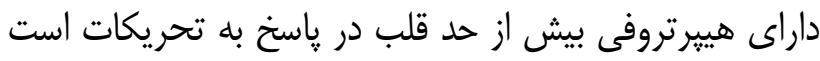
(^). به نظر مىرسد فعاليتهاى ورزشى با افزايش بير بيان

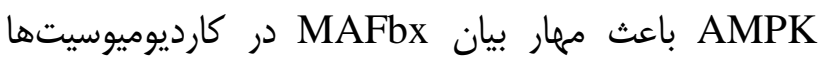
شده و از اين طريق از آتروفى قلب جلوگيرى مي كنى بئن. در اين

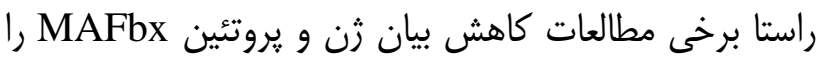

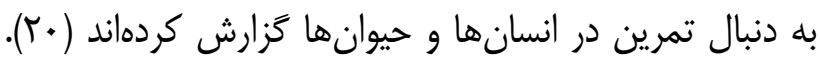
علاوه بر اين نشان داده شده است كه فعاليتهاى ورزشى دونى

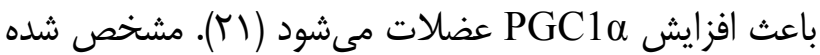
كه يروتئين تجزيه كننده بافت عضلانى FoxO، باعث كوفاكتور

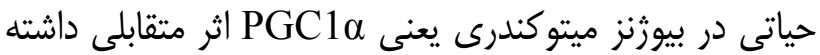

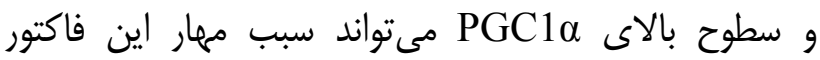
تخريب كننده يروتئين عضلانى شود (T) (T). FoxO3a واسطه
نتايج يثوهش حاضر نشان داد كه ديابت ناشى از STZ

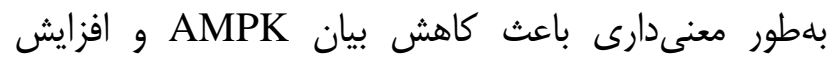

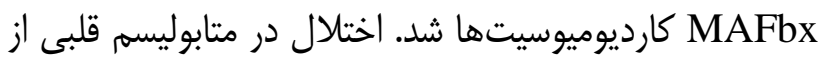

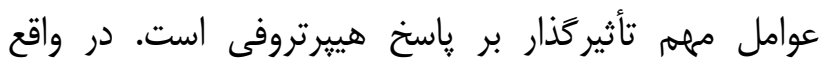
اختلال متابوليك، عامل اصلى اختلالات ساختارى و عملكرد عضله قلب مىباشد (T). Daniels و همكاران بيان كردند كه احس ديابت نوع دو در حيوانات بر فعالشدن AMPK تأثير منفى

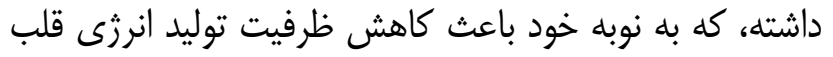

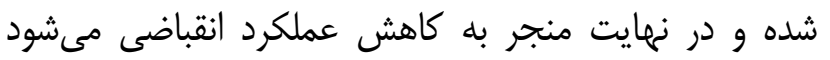

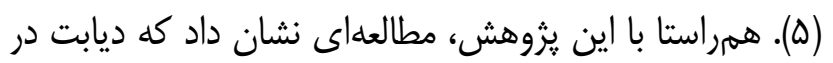

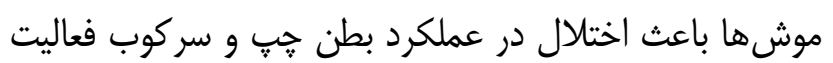
AMPK

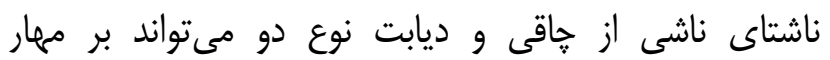

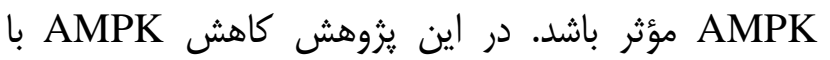

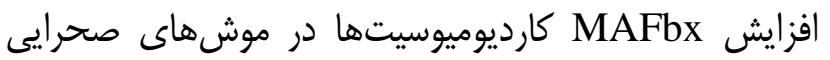

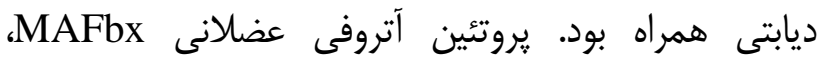
مسئول تخريب يروتئينهاى تعديل كننده يوبيكويتين مىباشد

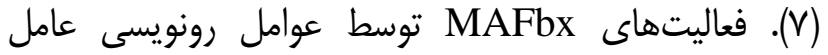

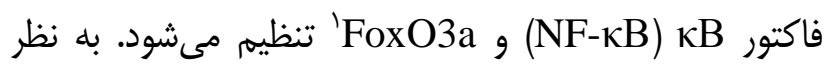
مىرسد فعالشدن FoxO3a سبب فعال مردن يروتئين تخريبكننده عضله يعنى MAFbx شده است. افزايش بيان MAFbx در برخى بيمارىها از قبيل ديابت نشان داده شده

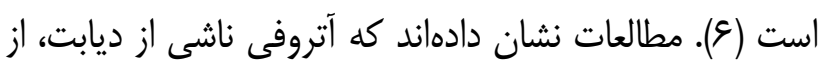

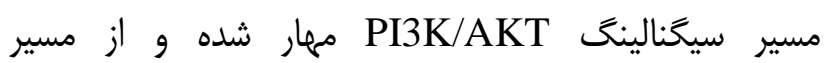
سيخنالينَ مقابل آن يعنى FoxO/MAFbx/MuRF1

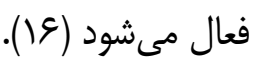
از ديخر نتايج ثيزوهش حاضر، افزايش بيان AMPK و كاهش بيان MAFbx ميوسيتهاى قلبى موش دهاى صحرايى بلهدنبال فعاليت ورزشى هوازى بود. افزايش فعاليت AMPK بلهعلت اختلالات در وضعيت انرزى قلب است. اين

\section{${ }^{1}$ Forkhead box 03}




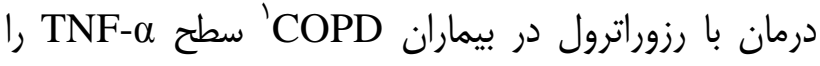

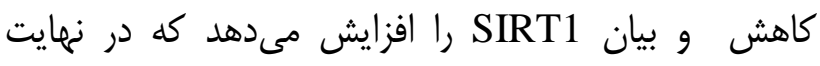
AMPK

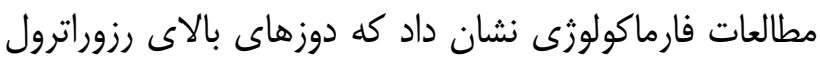

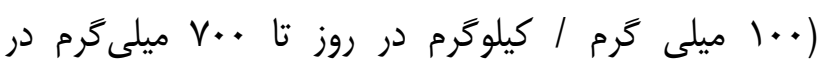

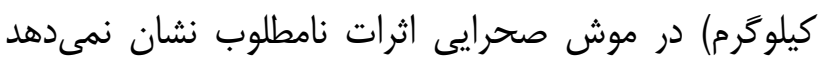

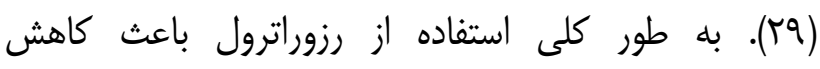

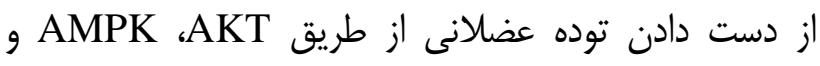

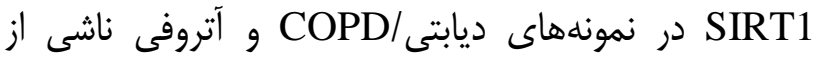

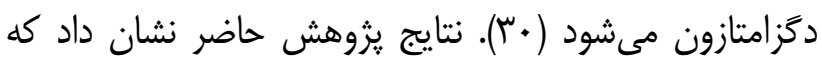

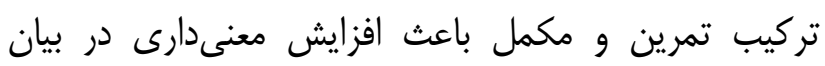

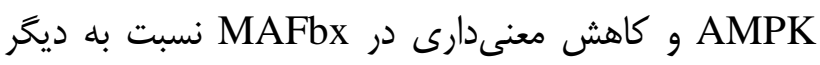

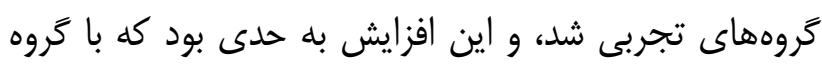

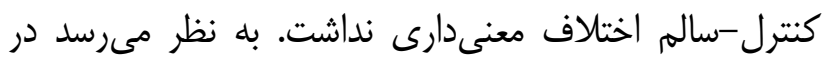

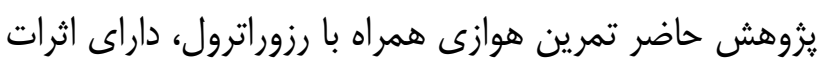

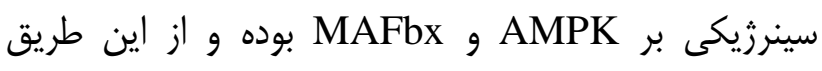

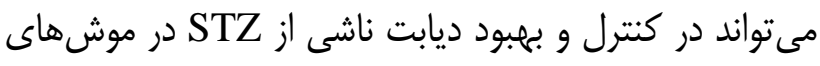
صحرايى مؤثر باشد.

از محدوديتهاى بزوهش حاضر، استفاده از تكنيكهاى

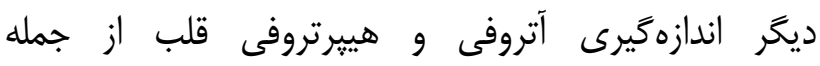

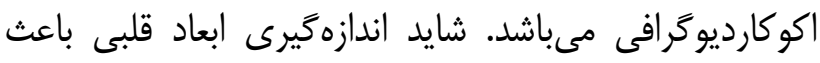

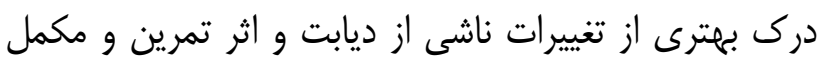

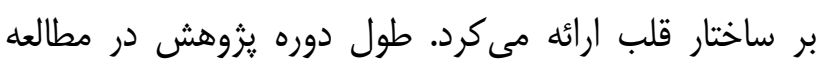

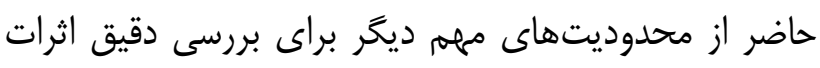

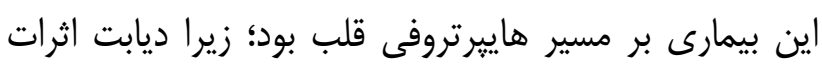
خود را در يك دوره طولانى بر جاى مى كَذارد.

\section{نتيجه كيرى}

نتايج مطالعه حاضر نشان داد كه ديابت باعث افزايش

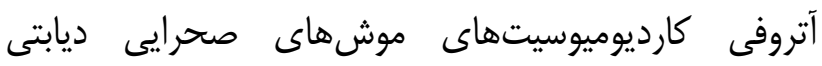

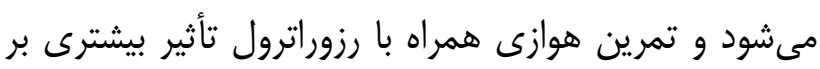

\footnotetext{
${ }^{1}$ Chronic obstructive pulmonary disease
}

اصلى در فرايند آتروزنز است و در صورتى كه فعال شود از

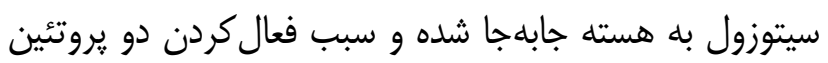
تخريبكننده بافت عضلانى يعنى MAFbx و و M مى كَردد و در نتيجه تخريب آغاز مى كَردد (سٓر).

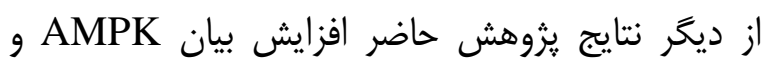

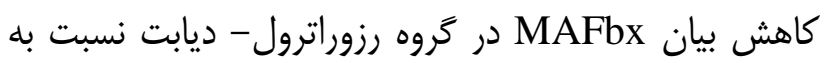
كروه ديابت بود. همجنين بيان AMPK و و

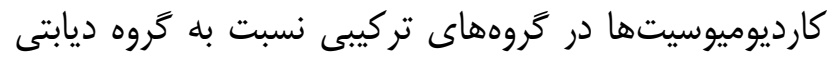

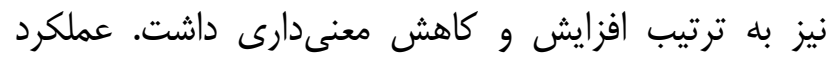

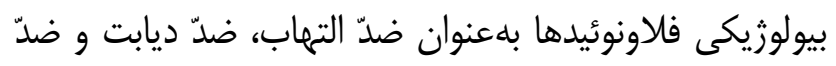

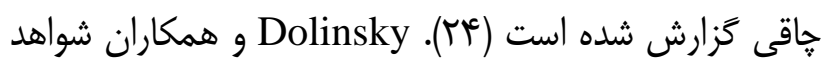

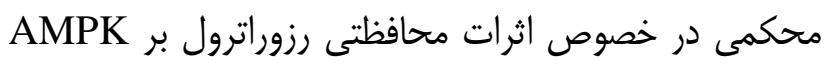

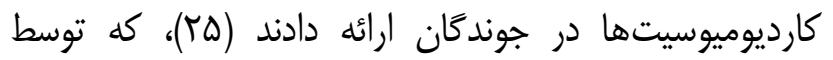

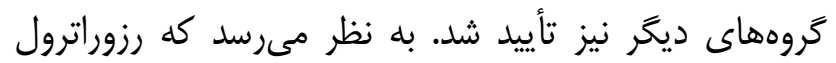

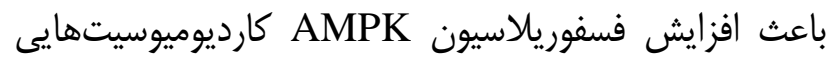

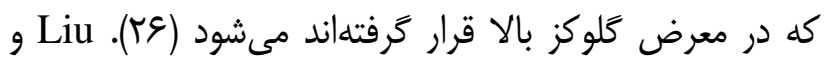
همكاران نيز در يخوهشى نشان دادند كه اليكونول (فلاونوئيد) با تنظيم كاهشى بيان MuRF1 و MAFbx باعث كاهش از دستدادن عضلات شده و تشكيل توبولها را را بهبود مى بخشان

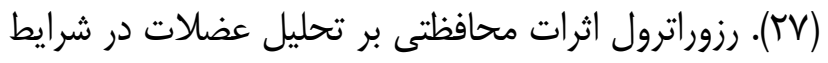

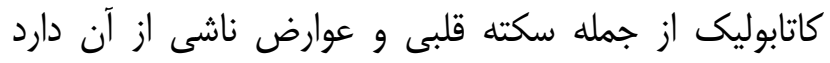

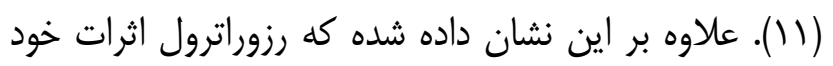

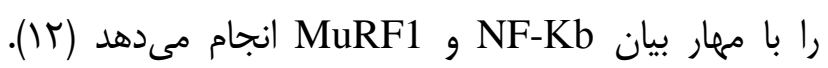

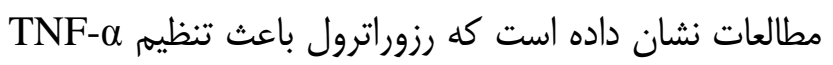

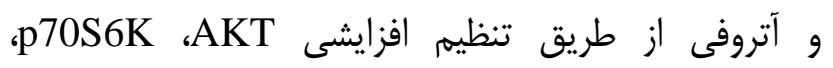

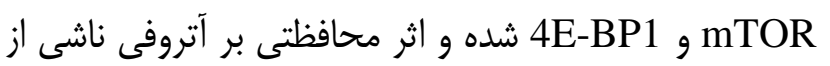

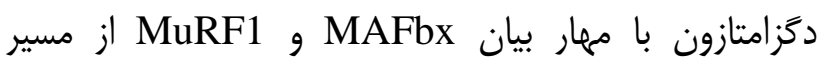
PGC-1 و Pارد (IRT1 القاشده با استريتوزوتوسين، تجويز رزوراترول باعث افزايش حساسيت به انسولين، افزايش فعاليت AMPK و فعاليت IL-) شده و همجنين بيان ثن سيتوكين هاى التهابى إنى

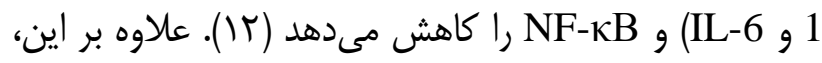




$$
\begin{aligned}
& \text { بهبود آتروفى ناشى از ديابت موشهاى صحرايى ديابتى دارد. شده است. بدينوسيله، نويسندكان تشكر و قدردانى خود را از } \\
& \text { اين واحد دانشگاهى اعلام مى دارند. } \\
& \text { اين يزوهش در قالب رساله دكترى رشته فيزيولوزى تضاد منافع } \\
& \text { نويسندگان مقاله اعلام مى دارند كه هيج كونه تضاد }
\end{aligned}
$$

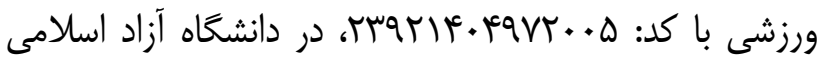

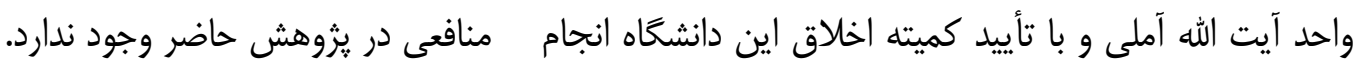

1- Falcão-Pires I, Leite-Moreira AF. Diabetic cardiomyopathy: understanding the molecular and cellular basis to progress in diagnosis and treatment. Heart Fail Rev. 2012; 17(3): 325-44. doi: 10.1007/s10741-011-9257-z.

2- Kundu BK, Zhong M, Sen S, Davogustto G, Keller SR, Taegtmeyer H. Remodeling of glucose metabolism precedes pressure overload-induced left ventricular hypertrophy: review of a hypothesis. Cardiology. 2015; 130(4): 211-20. doi: $10.1159 / 000369782$.

3- Tian R, Musi N, D'agostino J, Hirshman MF, Goodyear LJ. Increased adenosine monophosphate-activated protein kinase activity in rat hearts with pressure-overload hypertrophy. Circulation. 2001; 104(14): 1664-9. doi: 10.1161/hc4001.097183

4- Horman S, Beauloye C, Vanoverschelde JL, Bertrand L. AMP-activated protein kinase in the control of cardiac metabolism and remodeling. Curr Heart Fail Rep. 2012; 9(3): 164-73. doi: 10.1007/s11897-012-0102-z

5- Daniels A, Van Bilsen M, Janssen BJ, Brouns AE, Cleutjens JP, Roemen TH, et al. Impaired cardiac functional reserve in type 2 diabetic $\mathrm{db} / \mathrm{db}$ mice is associated with metabolic, but not structural, remodelling. Acta Physiol (Oxf). 2010; 200(1): 11-22. doi: 10.1111/j.1748-1716.2010.02102. x.

6- Bodine SC, Latres E, Baumhueter S, Lai VK, Nunez L, Clarke BA, et al. Identification of ubiquitin ligases required for skeletal muscle atrophy. Science. 2001; 294(5547): 1704-8. DOI: 10.1126/science.1065874

7- Hasselgren PO, Alamdari N, Aversa Z, Gonnella P, Smith IJ, Tizio S. Corticosteroids and muscle wasting role of transcription factors, nuclear cofactors, and hyperacetylation. Curr Opin Clin Nutr Metab Care. 2010; 13(4): 423-8. doi: 10.1097/MCO.0b013e32833a5107.

8- Li HH, Willis MS, Lockyer P, Miller N, McDonough H, Glass DJ, et al. Atrogin-1 inhibits Akt-dependent cardiac hypertrophy in mice via ubiquitin-dependent coactivation of Forkhead proteins. J Clin Invest. 2007; 117(11): 3211-23. doi: 10.1172/JCI31757

9- Liu HW, Chang SJ. Moderate exercise suppresses NF-kB signaling and activates the SIRT1-AMPK-PGC1a axis to attenuate muscle loss in diabetic db/db mice. Front Physiol. 2018; 9: 636. doi: 10.3389/fphys.2018.00636

10- Cantó C, Auwerx J. PGC-1alpha, SIRT1 and AMPK, an energy sensing network that controls energy expenditure. Curr Opin Lipidol. 2009; 20(2): 98-105. doi: 10.1097/MOL.0b013e328328d0a4.

11- Wang DT, Yin Y, Yang YJ, Lv PJ, Shi Y, Lu L, et al. Resveratrol prevents TNF- $\alpha$-induced muscle atrophy via regulation of Akt/mTOR/FoxO1 signaling in C2C12 myotubes. Int Immunopharmacol. 2014; 19(2): 206-13. doi: 10.1016/j.intimp.2014.02.002.

12- Shadfar S, Couch ME, McKinney KA, Weinstein LJ, Yin X, Rodríguez JE, et al. Oral resveratrol therapy inhibits cancer-induced skeletal muscle and cardiac atrophy in vivo. Nutr Cancer. 2011; 63(5): 749-62. doi: $10.1080 / 01635581.2011 .563032$

13- Batacan RB Jr, Duncan MJ, Dalbo VJ, Connolly KJ, Fenning AS. Light-intensity and high-intensity interval training improve cardiometabolic health in rats. Appl Physiol Nutr Metab. 2016; 41(9): 945-52. doi: 10.1139/apnm2016-0037. 
14- Hajighasem A, Farzanegi P, Mazaheri Z. Effects of combined therapy with resveratrol, continuous and interval exercises on apoptosis, oxidative stress, and inflammatory biomarkers in the liver of old rats with non-alcoholic fatty liver disease. Arch Physiol Biochem.. 2019; 125(2): 142-9. doi: 10.1080/13813455.2018.1441872.

15- Xie Z, Lau K, Eby B, Lozano P, He C, Pennington B, et al. Improvement of cardiac functions by chronic metformin treatment is associated with enhanced cardiac autophagy in diabetic OVE26 mice. Diabetes. 2011: 60(6): 1770-8. doi: $10.2337 / \mathrm{db} 10-0351$

16- Foletta VC, White LJ, Larsen AE, Léger B, Russell AP. The role and regulation of MAFbx/atrogin-1 and MuRF1 in skeletal muscle atrophy. Pflugers Arch. 2011; 461(3): 325-35. doi: 10.1007/s00424-010-0919-9.

17- Arad M, Seidman CE, Seidman JG. AMP-activated protein kinase in the heart: role during health and disease. Circ Res. 2007; 100(4): 474-88. doi: 10.1161/01.RES.0000258446.23525.37

18- Willis MS, Patterson C. Into the heart: the emerging role of the ubiquitin-proteasome system. J Mol Cell Cardiol. 2006; 41(4): 567-79. DOI: 10.1016/j.yjmcc.2006.07.015

19- Baskin KK, Rodriguez MR, Kansara S, Chen W, Carranza S, Frazier OH, et al. MAFbx/Atrogin-1 is required for atrophic remodeling of the unloaded heart. J Mol Cell Cardiol. 2014; 72: 168-76. doi: 10.1016/j.yjmcc.2014.03.006

20- Zanchi NE, de Siqueira Filho MA, Lira FS, Rosa JC, Yamashita AS, de Oliveira Carvalho CR, et al. Chronic resistance training decreases MuRF-1 and Atrogin-1 gene expression but does not modify Akt, GSK-3 $\beta$ and p70S6K levels in rats. Eur J Appl Physiol. 2009; 106(3): 415-23. doi: 10.1007/s00421-009-1033-6

21- Hood DA, Irrcher I, Ljubicic V, Joseph AM. Coordination of metabolic plasticity in skeletal muscle. J Exp Biol. 2006; 209(Pt 12): 2265-75. doi: 10.1242/jeb.02182

22- Puigserver P, Rhee J, Donovan J, Walkey CJ, Cliff Yoon J, OrienteF, et al. Insulin-regulated hepatic gluconeogenesis through FOXO1-PGC-1 $\alpha$ interaction. Nature. 2003; 423: 550-5. doi: 10.1038/nature01667

23- Sandri M, Sandri C, Gilbert A, Skurk C, Calabria E, Picard A, et al. Foxo transcription factors induce the atrophyrelated ubiquitin ligase atrogin-1 and cause skeletal muscle atrophy. Cell. 2004; 117(3): 399-412.

24- Liu HW, Wei CC, Chen YJ, Chen YA, Chang SJ. Flavanol-rich lychee fruit extract alleviates diet-induced insulin resistance via suppressing mTOR/SREBP-1 mediated lipogenesis in liver and restoring insulin signaling in skeletal muscle. Mol Nutr Food Res. 2016; 60(10): 2288-96. doi: 10.1002/mnfr.201501064. E

25- Dolinsky VW, Rogan KJ, Sung MM, Zordoky BN, Haykowsky MJ, Young ME, et al. Both aerobic exercise and resveratrol supplementation attenuate doxorubicin-induced cardiac injury in mice. Am J Physiol Endocrinol Metab. 2013; 305(2): E243-53. doi: 10.1152/ajpendo.00044.2013.

26- Guo S, Yao Q, Ke Z, Chen H, Wu J, Liu C. Resveratrol attenuates high glucose-induced oxidative stress and cardiomyocyte apoptosis through AMPK. Mol Cell Endocrinol. 2015; 412: 85-94. doi: 10.1016/j.mce.2015.05.034.

27- Liu HW, Chen YJ, Chang YC, Chang SJ. Oligonol, a low-molecular weight polyphenol derived from lychee, alleviates muscle loss in diabetes by suppressing atrogin-1 and MuRF1. Nutrients. 2017; 9(9): pii: E1040. doi: 10.3390/nu9091040.

28- Qi Y, Shang JY, Ma LJ, Sun BB, Hu XG, Liu B, et al. Inhibition of AMPK expression in skeletal muscle by systemic inflammation in COPD rats. Respir Res. 2014; 15: 156. doi: 10.1186/s12931-014-0156-4

29- Williams LD, Burdock GA, Edwards JA, Beck M, Bausch J. Safety studies conducted on high-purity transresveratrol in experimental animals. Food Chem Toxicol. 2009; 47(9): 2170-82. doi: 10.1016/j.fct.2009.06.002.

30- Dutt V, Gupta S, Dabur R, Injeti E, Mittal A. Skeletal muscle atrophy: potential therapeutic agents and their mechanisms of action. Pharmacol Res. 2015; 99: 86-100. doi: 10.1016/j.phrs.2015.05.010. 